\title{
Role of the ancillary ligands on the stabilization of the imino-oxo tautomer of 1-methylcytosine in $\mathrm{Pt}^{\mathrm{II}}$ complexes $\dagger$
}

\author{
Bruno Longato, ${ }^{a}$ Diego Montagner $^{a}$ and Ennio Zangrando ${ }^{b}$ \\ Received 20th October 2008, Accepted 24th December 2008 \\ First published as an Advance Article on the web 12th February 2009 \\ DOI: 10.1039/b818514j
}

The mixed nucleobases complexes $c i s-\left[\mathrm{L}_{2} \mathrm{Pt}\{1-\mathrm{MeTy}(-\mathrm{H})\}\left(1-\mathrm{MeCy}, N^{3}\right)\right] \mathrm{NO}_{3}\left(\mathrm{~L}=\mathrm{PPh}_{3}, \mathbf{1 a} ; \mathrm{PMePh}_{2}\right.$, 1b), containing the N(3)-deprotonated 1-methylthymine (1-MeTy(-H)) and the neutral

1-methylcytosine (1-MeCy) have been prepared and characterised. The compounds were obtained by reacting the hydroxo complexes cis- $\left[\mathrm{L}_{2} \mathrm{Pt}(\mu-\mathrm{OH})\right]_{2}\left(\mathrm{NO}_{3}\right)_{2}$ with 1-methylthymine (1-MeTy), followed by the addition of 1 equivalent of 1-MeCy. In solution of DMSO, DMF or chlorinated solvents, 1a converts quantitatively into the isomer $c i s-\left[\mathrm{L}_{2} \mathrm{Pt}\{1-\mathrm{MeTy}(-\mathrm{H})\}\left(1-\mathrm{MeCy}, N^{4}\right)\right] \mathrm{NO}_{3}$ (2a) containing the tautomeric form of the cytosine stabilized through the coordination at the N(4) atom, as shown by single-crystal X-ray analysis. The structural determination of $\mathbf{2 a}$ shows the presence in the unit cell of two crystallographic independent complexes having similar conformation, with a different orientation of the two nucleobases (head-head and head-tail) according to the presence of both isomers in solution. Complex 1b, having the less hindered $\mathrm{PMePh}_{2}$ ligands, in DMSO solution, contains the tautomeric forms of the cytosine in equilibrium and the migration of the metal from the $\mathrm{N}(3)$ to $\mathrm{N}(4)$ site occurs only to a minor extent.

\section{Introduction}

The usual metal binding site of the model nucleobase 1methylcytosine (1-MeCy) is the N(3) atom. ${ }^{1}$ However, the stabilization of the tautomeric form of this molecule through the coordination at the exocyclic $\mathrm{N}(4)$, in particular at $\mathrm{Pt}^{\mathrm{II}}$ centers, have been well documented. ${ }^{2}$ In all these cases, the initial coordination of the metal occurs at the N(3) site, followed by the metal migration at the N(4) position. Such isomerisation implies the shift of one of the exocyclic $\mathrm{NH}_{2}$ protons to the endocyclic $\mathrm{N}(3)$ atom of the cytosine ligand, as shown in Scheme $1 .^{3}$<smiles>[M]c1c(N)ccn(C)c1=O</smiles>

$\mathbf{A}$

Scheme 1<smiles>[M][W]=c1ccn(C)c(=O)[nH]1</smiles>

B
aDipartimento di Scienze Chimiche, Università di Padova, Via Marzolo 1, 35131, Padova, Italy. E-mail: bruno.longato@unipd.it; Tel: +39049 8275197; Fax: +390498275161

${ }^{b}$ Dipartimento di Scienze Chimiche, Università di Trieste, Via Giorgieri 1, 34127, Trieste, Italy

$\dagger$ Electronic supplementary information (ESI) available: ${ }^{15} \mathrm{~N}-{ }^{1} \mathrm{H}$ HMBC spectrum of 1b. CCDC reference number 705857 for compound 2a. For ESI and crystallographic data in CIF or other electronic format see DOI: $10.1039 / \mathrm{b} 818514 \mathrm{j}$
We have recently shown that the N(3)-bonded cytosine molecule in the mixed nucleobases complex cis- $\left[\left(\mathrm{PPh}_{3}\right)_{2} \mathrm{Pt}\{1-\mathrm{MeTy}(-\mathrm{H})\}(1-\right.$ $\left.\left.\mathrm{MeCy}, N^{3}\right)\right]^{+}$(1a) slowly rearranges into its more stable tautomeric derivative $c i s-\left[\left(\mathrm{PPh}_{3}\right)_{2} \mathrm{Pt}\{1-\mathrm{MeTy}(-\mathrm{H})\}\left(1-\mathrm{MeCy}, N^{4}\right)\right]^{+}$(2a). ${ }^{4}$

In this paper we report the structural characterisation of this compound by single-crystal X-ray analysis showing that the binding mode of the cytosine, previously established in solution by multinuclear NMR techniques, is maintained in the solid state. Moreover, the role of the $\mathrm{PPh}_{3}$ ligands in the stabilization of the cytosine iminooxo tautomer has been further investigated by preparing the complex cis-[(PMePh$)_{2} \mathrm{Pt}\{1-\mathrm{MeTy}(-$ $\left.\mathrm{H})\}\left(1-\mathrm{MeCy}, N^{3}\right)\right]^{+}$, 1b, containing the less hindered $\mathrm{PMePh}_{2}$ ligands. This simple change of the metal coordination sphere strongly effects the relative stability of the tautomeric forms of the cytosine ligand since the platination at the N(3) site appears largely predominant in a DMSO solution of $\mathbf{1 b}$.

\section{Experimental}

\section{Synthesis and materials}

cis- $\left[\left(\mathrm{PMePh}_{2}\right)_{2} \mathrm{Pt}(\mu-\mathrm{OH})\right]_{2}\left(\mathrm{NO}_{3}\right)_{2}{ }^{5}$ and $1-\mathrm{MeCy}^{6}$ were prepared as previously reported. cis-[( $\left.\left.\mathrm{PPh}_{3}\right)_{2} \mathrm{Pt}\{1-\mathrm{MeTy}(-\mathrm{H})\}\left(1-\mathrm{MeCy}, N^{4}\right)\right]-$ $\mathrm{NO}_{3}$ was prepared as described in reference [4] and the sample for X-ray analysis was obtained by slow diffusion of $\mathrm{Et}_{2} \mathrm{O}$ into a DMF solution of the compound, at room temperature. 1-MeTy and all the solvents $\left(\mathrm{CH}_{2} \mathrm{Cl}_{2}\right.$, DMF, DMSO- $\left.d_{6}, \mathrm{CDCl}_{3}, \mathrm{Et}_{2} \mathrm{O}\right)$ were Aldrich products.

cis-(PMePh $)_{2} \mathbf{P t}\{1-\mathrm{MeTy}(-\mathrm{H})\}\left(\mathrm{ONO}_{2}\right)$. To a solution of cis$\left[\left(\mathrm{PMePh}_{2}\right)_{2} \mathrm{Pt}(\mu-\mathrm{OH})\right]_{2}\left(\mathrm{NO}_{3}\right)_{2}\left(48.6 \mathrm{mg}, 3.6 \cdot 10^{-2} \mathrm{mmol}\right)$ in $\mathrm{CH}_{2} \mathrm{Cl}_{2}$ $\left(3 \mathrm{~cm}^{3}\right)$ 1-MeTy $\left(11.0 \mathrm{mg}, 7.8 \cdot 10^{-2} \mathrm{mmol}\right)$ was added, and the suspension stirred at room temperature for ca. $12 \mathrm{~h}$. Addition of pentane $\left(25 \mathrm{~cm}^{3}\right)$ to the resulting solution afforded a white 
solid which was isolated and dried under vacuum. Purification of the solid from $\mathrm{CHCl}_{3}$, by vapour diffusion of $\mathrm{Et}_{2} \mathrm{O}$ at room temperature, afforded crystals having the composition cis$\left(\mathrm{PMePh}_{2}\right)_{2} \mathrm{Pt}\{1-\mathrm{MeTy}(-\mathrm{H})\}\left(\mathrm{ONO}_{2}\right) \cdot 1 \mathrm{H}_{2} \mathrm{O} \cdot 1 / 4 \mathrm{CH}_{2} \mathrm{Cl}_{2}$. (50.4 mg, $85 \%$ ). (Found: $\mathrm{C}, 46.46 ; \mathrm{H}, 4.02 ; \mathrm{N}, 5.00 . \mathrm{C}_{32.25} \mathrm{H}_{35.5} \mathrm{~N}_{3} \mathrm{Cl}_{0.5} \mathrm{O}_{6} \mathrm{P}_{2} \mathrm{Pt}$ requires $\mathrm{C}, 46.34 ; \mathrm{H}, 4.29 ; \mathrm{N}, 5.02) . \delta_{\mathrm{H}}\left(300.13 \mathrm{MHz} ; \mathrm{CDCl}_{3}\right.$; $\left.\mathrm{Me}_{4} \mathrm{Si}\right) 7.69-7.23\left(20 \mathrm{H}, \mathrm{cm}, \mathrm{PPh}_{2}\right), 6.38(1 \mathrm{H}, \mathrm{s}, \mathrm{H} 6), 3.03(3 \mathrm{H}, \mathrm{s}$, $\left.\mathrm{NCH}_{3}\right), 1.89\left(3 \mathrm{H}, \mathrm{d},{ }^{2} \mathrm{~J}_{\mathrm{HP}} 11.6, \mathrm{PMe}\right), 1.80\left(3 \mathrm{H}, \mathrm{d},{ }^{2} \mathbf{J}_{\mathrm{HP}} 11.6, \mathrm{PMe}\right)$, $1.65\left(3 \mathrm{H}, \mathrm{s}, \mathrm{CCH}_{3}\right) ; \delta_{\mathrm{H}}\left(300.13 \mathrm{MHz} ; \mathrm{DMSO}-d_{6} ; \mathrm{Me}_{4} \mathrm{Si}\right) 7.64-7.25$ $\left(20 \mathrm{H}, \mathrm{cm}, \mathrm{PPh}_{2}\right), 6.84(1 \mathrm{H}, \mathrm{s}, \mathrm{H} 6), 2.96\left(3 \mathrm{H}, \mathrm{s}, \mathrm{NCH}_{3}\right), 2.09(3 \mathrm{H}$, $\left.\mathrm{d},{ }^{2} \mathrm{~J}_{\mathrm{HP}} 12, \mathrm{PMe}\right), 1.75\left(3 \mathrm{H}, \mathrm{d},{ }^{2} \mathrm{~J}_{\mathrm{HP}} 12, \mathrm{PMe}\right), 1.50 \mathrm{~s}\left(3 \mathrm{H}, \mathrm{s}, \mathrm{CCH}_{3}\right)$. $\delta_{\mathrm{P}}\left(121.5 \mathrm{MHz} ; \mathrm{CDCl}_{3}\right) \mathrm{AB}$ multiplet $-5.32\left(1 \mathrm{P}, \mathrm{d},{ }^{1} \mathrm{~J}_{\mathrm{PPt}} 3284\right)$, $-13.74\left(1 \mathrm{P}, \mathrm{d},{ }^{1} \mathrm{~J}_{\mathrm{PPt}} 4062,{ }^{2} \mathrm{~J}_{\mathrm{PP}} 23.1\right) . \delta_{\mathrm{P}}\left(121.5 \mathrm{MHz}\right.$; DMSO- $\left.d_{6}\right)$ AB multiplet $-2.58\left(1 \mathrm{P}, \mathrm{d},{ }^{1} \mathrm{~J}_{\mathrm{PPt}} 3241\right),-11.17\left(1 \mathrm{P}, \mathrm{d},{ }^{1} \mathrm{~J}_{\mathrm{PPt}} 4108\right.$, $\left.{ }^{2} \mathrm{~J}_{\mathrm{PP}}=24.3\right)$.

cis- $\left[\left(\mathbf{P M e P h}_{2}\right)_{2} \mathbf{P t}\{1-\mathrm{MeTy}(-\mathrm{H})\}\left(1-\mathrm{MeCy}, \boldsymbol{N}^{3}\right)\right] \mathrm{NO}_{3}$ (1b). To a solution of cis- $\left(\mathrm{PMePh}_{2}\right)_{2} \mathrm{Pt}\{1-\mathrm{MeTy}(-\mathrm{H})\}\left(\mathrm{ONO}_{2}\right) \quad(31 \mathrm{mg}$, $\left.3.8 \cdot 10^{-2} \mathrm{mmol}\right)$ in $3 \mathrm{~cm}^{3}$ of $\mathrm{CH}_{2} \mathrm{Cl}_{2}$ was added $1-\mathrm{MeCy}(5.0 \mathrm{mg}$, $3.9 \cdot 10^{-2} \mathrm{mmol}$ ) which, under stirring at room temperature, dissolved in a few $\mathrm{h}$. Addition of $\mathrm{Et}_{2} \mathrm{O}$ afforded a white solid that after filtration, washing with $\mathrm{Et}_{2} \mathrm{O}$ and dried under vacuum had the composition cis-[( $\left.\mathrm{PMePh}_{2}\right)_{2} \mathrm{Pt}\{1-\mathrm{MeTy}(-\mathrm{H})\}(1-$ $\left.\left.\mathrm{MeCy}, N^{3}\right)\right] \mathrm{NO}_{3} \cdot 1 \mathrm{H}_{2} \mathrm{O} \cdot 1 / 4 \mathrm{CH}_{2} \mathrm{Cl}_{2}(24.9 \mathrm{mg}, 71 \%$ ). (Found: $\mathrm{C}$, 46.12; H, 4.08; N, 8.44. $\mathrm{C}_{37,25} \mathrm{H}_{42,5} \mathrm{~N}_{6} \mathrm{O}_{7} \mathrm{Cl}_{0,5} \mathrm{P}_{2} \mathrm{Pt}$ requires $\mathrm{C}, 46.55$; $\mathrm{H}, 4.47 ; \mathrm{N}, 8.74) . \delta_{\mathrm{H}}\left(300.13 \mathrm{MHz} ; \mathrm{CDCl}_{3} ; \mathrm{Me}_{4} \mathrm{Si}\right) 7.86-7.21(20 \mathrm{H}$, $\left.\mathrm{cm}, \mathrm{PPh}_{2}\right), 1.34\left(3 \mathrm{H}, \mathrm{d},{ }^{2} \mathrm{~J}_{\mathrm{HP}} 11, \mathrm{PCH}_{3}\right), 1.32\left(3 \mathrm{H}, \mathrm{d},{ }^{2} \mathrm{~J}_{\mathrm{HP}} 11, \mathrm{PCH}_{3}\right)$. Main conformer (1-MeTy(-H) resonances): $6.31(1 \mathrm{H}, \mathrm{s}, \mathrm{H} 6), 2.99$ $\left(3 \mathrm{H}, \mathrm{s}, \mathrm{NCH}_{3}\right), 1.56\left(3 \mathrm{H}, \mathrm{s}, \mathrm{CCH}_{3}\right)$; (1-MeCy resonances): 8.69 $(1 \mathrm{H}$, br s, NH), $8.60(1 \mathrm{H}$, br s, NH), $6.63(1 \mathrm{H}, \mathrm{d}, \mathrm{J} 7.1, \mathrm{H} 6)$, $6.06\left(1 \mathrm{H}, \mathrm{d}, \mathrm{J}\right.$ 7.1, H5), $2.98\left(3 \mathrm{H}, \mathrm{s}, \mathrm{NCH}_{3}\right)$. Minor conformer: (1-MeTy $(-\mathrm{H})$ resonances): $6.27(1 \mathrm{H}, \mathrm{s}, \mathrm{H} 6), 2.85\left(3 \mathrm{H}, \mathrm{s}, \mathrm{NCH}_{3}\right)$, $1.58\left(3 \mathrm{H}, \mathrm{s}, \mathrm{CCH}_{3}\right),(1-\mathrm{MeCy}$ resonances): $8.75(1 \mathrm{H}, \mathrm{br} \mathrm{s}, \mathrm{NH})$, $8.63(1 \mathrm{H}, \mathrm{br} \mathrm{s}, \mathrm{NH}), 6.61(1 \mathrm{H}, \mathrm{d}, \mathrm{J} 7.2, \mathrm{H} 6), 6.10(1 \mathrm{H}, \mathrm{d}, \mathrm{J} 7.2$, $\mathrm{H} 5), 3.02\left(3 \mathrm{H}, \mathrm{s}, \mathrm{NCH}_{3}\right) . \delta_{\mathrm{H}}\left(300.13 \mathrm{MHz} ; \mathrm{DMSO}-d_{6} ; \mathrm{Me}_{4} \mathrm{Si}\right) 8.01-$ $7.39\left(20 \mathrm{H}, \mathrm{cm}, \mathrm{PPh}_{2}\right), 1.64\left(3 \mathrm{H}, \mathrm{d},{ }^{2} \mathrm{~J}_{\mathrm{HP}} 10.3, \mathrm{PCH}_{3}\right), 1.63(3 \mathrm{H}, \mathrm{d}$, $\left.{ }^{2} \mathrm{~J}_{\mathrm{HP}} 10.3, \mathrm{PCH}_{3}\right)$. Main conformer (1-MeTy(-H) resonances): 6.72 $(1 \mathrm{H}, \mathrm{s}, \mathrm{H} 6), 2.89\left(3 \mathrm{H}, \mathrm{s}, \mathrm{NCH}_{3}\right), 1.41\left(3 \mathrm{H}, \mathrm{s}, \mathrm{CCH}_{3}\right) ;(1-\mathrm{MeCy}$ resonances): $8.75(1 \mathrm{H}$, br s, NH), $8.37(1 \mathrm{H}, \mathrm{br} \mathrm{s}, \mathrm{NH}), 7.21(1 \mathrm{H}$, d, J 7.1, H6), $5.42\left(1 \mathrm{H}, \mathrm{d}, \mathrm{J}\right.$ 7.1, H5), $2.93\left(3 \mathrm{H}, \mathrm{s}, \mathrm{NCH}_{3}\right)$. Minor conformer: (1-MeTy $(-\mathrm{H})$ resonances): $6.68(1 \mathrm{H}, \mathrm{s}, \mathrm{H} 6), 2.89(3 \mathrm{H}$, s, $\left.\mathrm{NCH}_{3}\right), 1.38\left(3 \mathrm{H}, \mathrm{s}, \mathrm{CCH}_{3}\right),(1-\mathrm{MeCy}$ resonances): $8.68(1 \mathrm{H}, \mathrm{br}$ s, NH), $8.37(1 \mathrm{H}$, br s, NH), $7.21(1 \mathrm{H}, \mathrm{d}, \mathrm{J} 7.1, \mathrm{H} 6), 5.42(1 \mathrm{H}, \mathrm{d}$, J 7.1, H5), $2.93\left(3 \mathrm{H}, \mathrm{s}, \mathrm{NCH}_{3}\right)$. $\delta_{\mathrm{P}}\left(121.5 \mathrm{MHz} ; \mathrm{CDCl}_{3}\right)$, minor conformer: $\mathrm{AB}$ multiplet $-11.48\left(1 \mathrm{P}, \mathrm{d},{ }^{1} \mathrm{~J}_{\mathrm{PPt}} 3249\right),-13.17(1 \mathrm{P}, \mathrm{d}$, $\left.{ }^{1} \mathrm{~J}_{\mathrm{PPt}} 3489,{ }^{2} \mathrm{~J}_{\mathrm{PP}} 24.4\right)$; main conformer: $\mathrm{AB}$ multiplet -11.75 (1P, $\left.\mathrm{d},{ }^{1} \mathrm{~J}_{\mathrm{PPt}} 3249\right),-13.17\left(1 \mathrm{P}, \mathrm{d},{ }^{1} \mathrm{~J}_{\mathrm{PPt}} 3485,{ }^{2} \mathrm{~J}_{\mathrm{PP}} 24.4\right)$. $\delta_{\mathrm{P}}(121.5 \mathrm{MHz}$; DMSO- $\left.d_{6}\right)$, minor conformer: $\mathrm{AB}$ multiplet $-9.83\left(1 \mathrm{P}, \mathrm{d},{ }^{1} \mathrm{~J}_{\mathrm{PPt}}\right.$ 3224), -11.82 (1P, d, ${ }^{1} \mathrm{~J}_{\mathrm{PPt}} 3495,{ }^{2} \mathrm{~J}_{\mathrm{PP}}$ 24.7); main conformer: $\mathrm{AB}$ multiplet $-10.11\left(1 \mathrm{P}, \mathrm{d},{ }^{1} \mathrm{~J}_{\mathrm{PPt}} 3224\right),-11.88\left(1 \mathrm{P}, \mathrm{d},{ }^{1} \mathrm{~J}_{\mathrm{PPt}} 3495\right.$, $\left.{ }^{2} \mathbf{J}_{\mathrm{PP}} 24.3\right)$.

\section{NMR measurements}

NMR spectra were obtained in solution of various solvents at $298 \mathrm{~K}$, with a Bruker AVANCE $300 \mathrm{MHz}$ for ${ }^{1} \mathrm{H}$ and ${ }^{31} \mathrm{P}$ (operating at 300.13 and $121.5 \mathrm{MHz}$, respectively) and a Bruker 400 AMX-WB spectrometer for ${ }^{15} \mathrm{~N}$ (operating at $40.6 \mathrm{MHz}$ ). $\delta$ are in ppm and $\mathbf{J}$ in $\mathrm{Hz}$. The ${ }^{1} \mathrm{H}$ chemical shifts were referenced to the residual impurity of the solvent and to $\mathrm{Me}_{4} \mathrm{Si}$. The external refer- ences were $\mathrm{H}_{3} \mathrm{PO}_{4}\left(85 \mathrm{w} / \mathrm{w}\right.$ in $\mathrm{D}_{2} \mathrm{O}$ ) for ${ }^{31} \mathrm{P}$, and $\mathrm{CH}_{3} \mathrm{NO}_{2}$ (in $\mathrm{CDCl}_{3}$ at $50 \% \mathrm{w} / \mathrm{w}$ ) for ${ }^{15} \mathrm{~N}$. Inverse detected spectra were obtained through heteronuclear multiple bond correlation (HMBC) experiments, using parameters similar to those previously reported. ${ }^{7}$

\section{X-Ray structure determination}

Diffraction data for compound 2a were collected at room temperature on a Nonius DIP-1030H system with Mo-K $\alpha$ radiation $(\lambda=0.71073 \AA)$. Cell refinement, indexing and scaling of the data set were carried out using programs Denzo ${ }^{8}$ and Scalepack. ${ }^{8}$ The structure was solved by direct method and subsequent Fourier analyses $^{9}$ and refined by the full-matrix least-squares method based on $F^{2}$ with all observed reflections. ${ }^{9}$ A residual in the $\Delta \mathrm{F}$ map was interpreted as a lattice water oxygen (hydrogen atoms not located). All the calculations were performed using the WinGX System, Ver 1.70.01. ${ }^{10}$

Crystal data of $2 \mathrm{a} \cdot 0.5\left(\mathrm{H}_{2} \mathrm{O}\right): \mathrm{C}_{47} \mathrm{H}_{45} \mathrm{~N}_{6} \mathrm{O}_{6.50} \mathrm{P} 2 \mathrm{Pt}, \mathrm{M}=1054.92$, triclinic, space group $P \overline{1}, a=14.868(4), b=17.155(4), c=$ 22.120(5) $\AA, \alpha=105.94(2), \beta=96.01(3), \gamma=112.59(3)^{\circ}, V=$ $4866(2) \AA^{3}, \mathrm{Z}=4, D_{c}=1.440 \mathrm{~g} / \mathrm{cm}^{3}, \mu(\mathrm{Mo}-\mathrm{K} \alpha)=3.002 \mathrm{~mm}^{-1}$, $F(000)=2116, \theta$ range $=1.53-25.35^{\circ}$. Final $R 1=0.0521, w R 2=$ $0.1262, S=0.768$ for 1086 parameters and 58142 reflections, 15539 unique $[\mathrm{R}($ int $)=0.0674]$, of which 6194 with $I>2 \sigma(I)$, $\max$ positive and negative peaks in $\Delta F$ map $1.101,-0.776 \mathrm{e} \cdot \AA^{-3}$.

\section{Results and discussion}

\section{Crystal and molecular structure of cis- $\left[\left(\mathbf{P P h}_{3}\right)_{2} \mathbf{P t}\{1-\mathrm{MeTy}(-\mathrm{H})\}\left(1-\mathrm{MeCy}, N^{4}\right) \mathrm{NO}_{3}\right.$ (2a)}

We have recently shown that cis-[( $\left.\left.\mathrm{PPh}_{3}\right)_{2} \mathrm{Pt}(\mu-\mathrm{OH})\right]_{2}\left(\mathrm{NO}_{3}\right)_{2}$ reacts with 1-MeTy, in $\mathrm{CH}_{2} \mathrm{Cl}_{2}$, DMF or $\mathrm{CH}_{3} \mathrm{CN}$, affording the neutral complex cis- $\left(\mathrm{PPh}_{3}\right)_{2} \mathrm{Pt}\{1-\mathrm{MeTy}(-\mathrm{H})\}\left(\mathrm{ONO}_{2}\right)$ in which the thyminato ligand is $\mathrm{N}(3)$ platinated and the nitrato group acts as monodentate ligand. ${ }^{4}$ Addition of one equivalent of 1$\mathrm{MeCy}$ leads to the mixed complex cis-[( $\left.\mathrm{PPh}_{3}\right)_{2} \mathrm{Pt}\{1-\mathrm{MeTy}(-\mathrm{H})\}(1-$ $\left.\left.\mathrm{MeCy}, N^{3}\right)\right] \mathrm{NO}_{3}$ (1a), resulting in the immediate replacement of the nitrato ligand. The deprotonated 1-MeTy and the neutral 1$\mathrm{MeCy}$, are both platinated at the $\mathrm{N}(3)$ atom. In a few days at room temperature in chlorinated solvents, DMSO or DMF, 1a converts into the isomer cis- $\left[\left(\mathrm{PPh}_{3}\right)_{2} \mathrm{Pt}\{1-\mathrm{MeTy}(-\mathrm{H})\}\left(1-\mathrm{MeCy}, N^{4}\right)\right] \mathrm{NO}_{3}$, 2a, in which the cytosine is coordinated to the metal through the exocyclic N(4) atom, as shown by multinuclear NMR studies in solution and now confirmed in the solid state.

The X-ray structural determination of 2a shows the presence in the unit cell of two crystallographic independent complexes (A and B), disordered nitrate anions and a lattice water molecule. The metal ion has a square planar coordination geometry achieved through the phosphorous atoms and the nitrogen donors of the nucleobases. The thyminato is bound through the endocyclic N(3) atom, the cytosine through the deprotonated amino group N(4) (Fig. 1 and 2 and Table 1).

The atoms of the coordination $\mathrm{N}_{2} \mathrm{P}_{2}$ plane are almost coplanar with max deviations of $\pm 0.02 \AA$. The two complexes are conformationally very similar, differing slightly in the orientation of the nucleobase and phenyl rings. The position of the thymine $\mathrm{N}(1)$ nitrogen atom was not definitely assigned, having a pseudo two-fold axis that does not allow differentiation on the $\Delta$ Fourier 


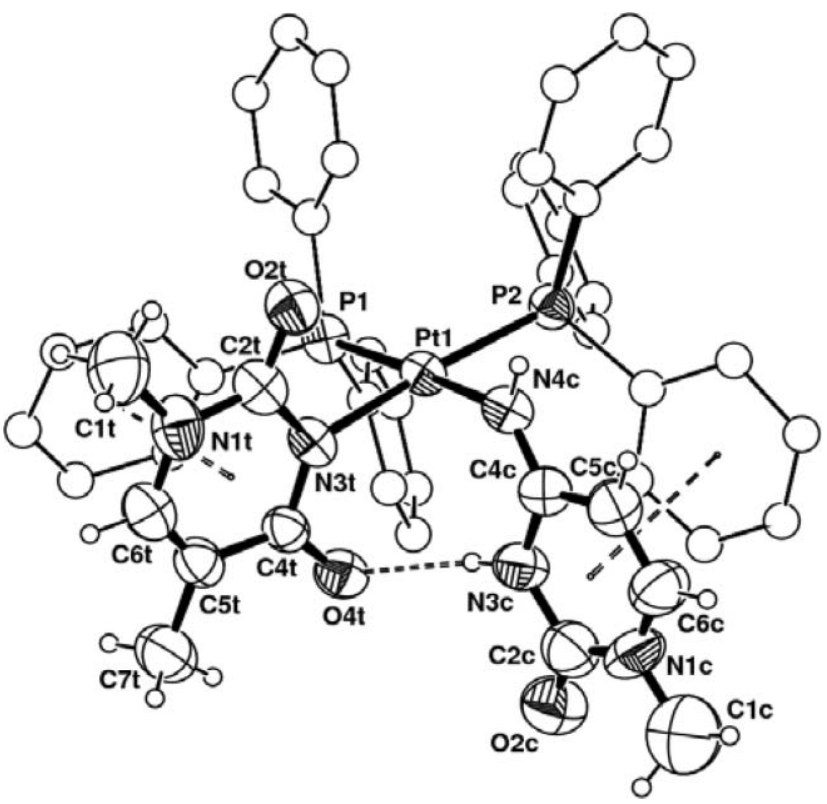

Fig. 1 ORTEP drawing of complex cation A (head-tail orientation of the bases) with indication of the intramolecular $\mathrm{H}$-bond and $\pi-\pi$ stacking interactions.

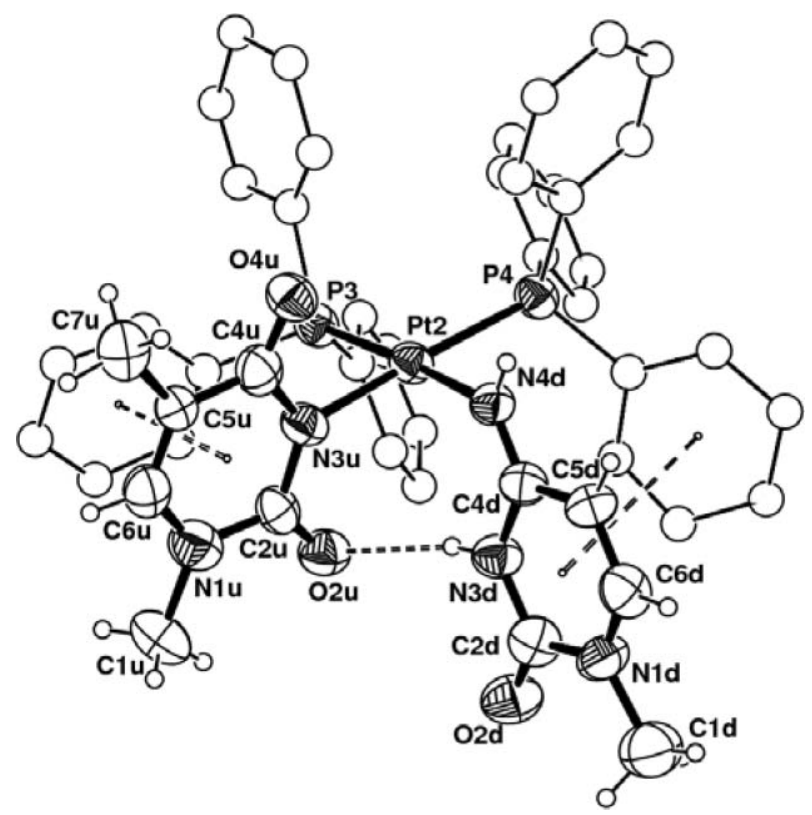

Fig. 2 ORTEP drawing of complex cation B (head-head orientation, the cytosine and thymine bases are labelled as "d" and "u", respectively).

map of the endocyclic N(1) and C(5) atoms. Based on the thermal parameters values and bond distances, we tentatively assigned the $\mathrm{N}(1)$ thymine atom in the two complexes corresponding to the two possible head-to-head and head-to-tail conformational isomers present in solution. In the head-to-head $(h h)$ and head-totail $(h t)$ conformations the methyl group on cytosine and thymine $\mathrm{N} 1$ nitrogen atoms lie on the same and on the opposite side, respectively, of the $\mathrm{P}_{2} \mathrm{Pt}$ plane (see Scheme 2). On the other hand, in both molecules the hydrogen at the cytosine N(3) atom (close to the metal) is indicative of a syn isomer. ${ }^{4}$
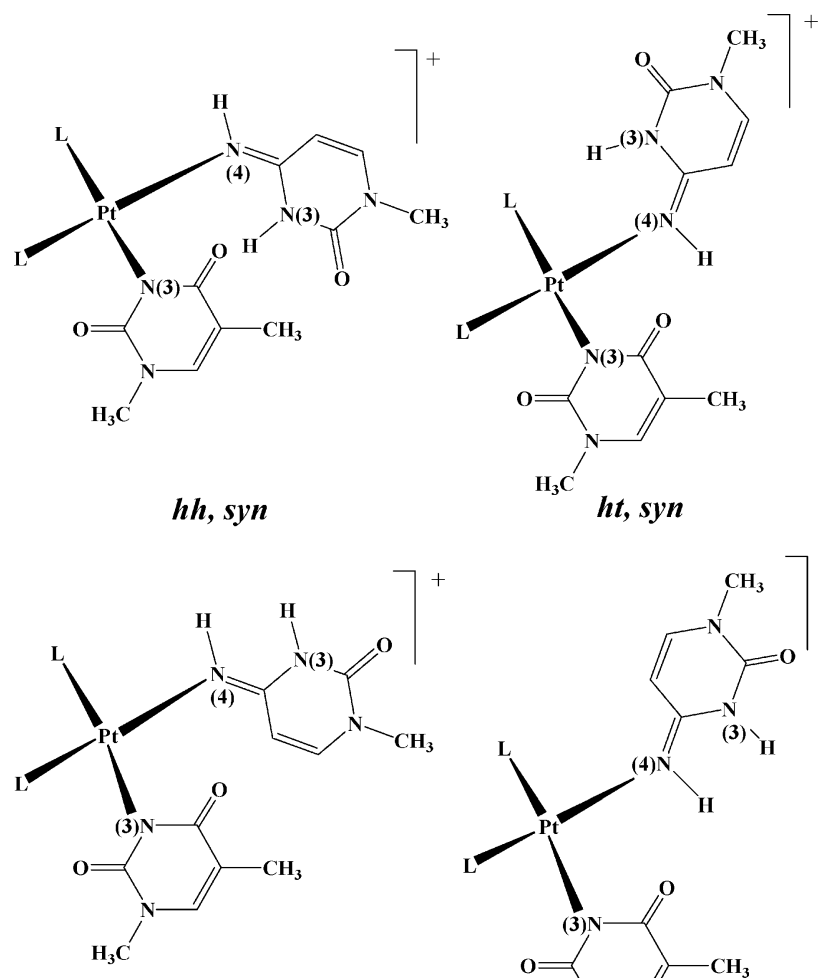

hh, anti

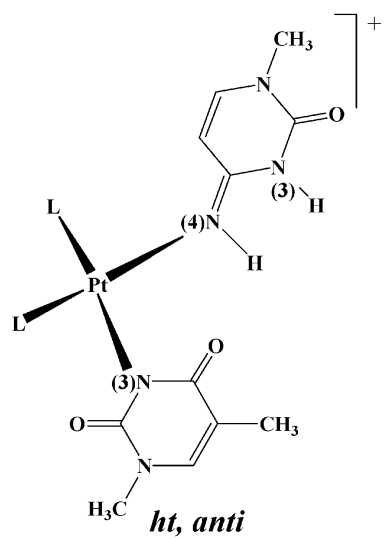

$$
\mathbf{L}=\mathbf{P P h}_{3}
$$

Scheme 2

The bond lengths and angles in the two independent complexes (not highly accurate) fall in a wide range, comparable within $2-3 \sigma$ (Table 1). These data indicate that the $\mathrm{Pt}-\mathrm{N}(3)$ (thyminato) bond distances $(2.095(8)$ and 2.045(9) $\AA$ ) appear shorter with respect to the Pt-N(4)(cytosine) ones (2.110(9) and 2.089(8) $\AA$ ). The coordination bond angle $\mathrm{C}(4 \mathrm{c})-\mathrm{N}(4 \mathrm{c})-\mathrm{Pt}(1)$ at cytosine is also very similar in the two complexes with a mean value of $127.1(9)^{\circ}$. The N(3t)-Pt-N(4c) angle, 87.2(3) and $86.5(3)^{\circ}$ in complexes A and $\mathrm{B}$, respectively, is narrower in contrast to the $\mathrm{P}(1)-\mathrm{Pt}-\mathrm{P}(2)$ one that average to $96.3^{\circ}$, likely induced by steric requirements. The thymine base is oriented almost normal to the coordination mean plane forming a dihedral angle of $82.88^{\circ}$ (average value in the two complexes), while the cytosine plane is more bent, and its

Table 1 Coordination bond lengths and angles for the two independent complexes

\begin{tabular}{lcc}
\hline & Complex A & Complex B \\
\hline $\mathrm{Pt}(1)-\mathrm{N}(3 \mathrm{t})$ & $2.095(8)$ & $2.045(9)$ \\
$\mathrm{Pt}(1)-\mathrm{N}(4 \mathrm{c})$ & $2.110(9)$ & $2.089(8)$ \\
$\mathrm{Pt}(1)-\mathrm{P}(1)$ & $2.274(3)$ & $2.281(3)$ \\
$\mathrm{Pt}(1)-\mathrm{P}(2)$ & $2.286(3)$ & $2.272(3)$ \\
$\mathrm{N}(3 \mathrm{t})-\mathrm{Pt}(1)-\mathrm{N}(4 \mathrm{c})$ & $87.2(3)$ & $86.5(3)$ \\
$\mathrm{N}(3 \mathrm{t})-\mathrm{Pt}(1)-\mathrm{P}(1)$ & $88.9(2)$ & $89.4(3)$ \\
$\mathrm{N}(3 \mathrm{t})-\mathrm{Pt}(1)-\mathrm{P}(2)$ & $174.8(3)$ & $174.0(2)$ \\
$\mathrm{N}(4 \mathrm{c})-\mathrm{Pt}(1)-\mathrm{P}(1)$ & $175.9(2)$ & $175.9(2)$ \\
$\mathrm{N}(4 \mathrm{c})-\mathrm{Pt}(1)-\mathrm{P}(2)$ & $87.9(2)$ & $87.6(2)$ \\
$\mathrm{P}(1)-\mathrm{Pt}(1)-\mathrm{P}(2)$ & $96.13(11)$ & $96.48(12)$ \\
$\mathrm{C}(4 \mathrm{c})-\mathrm{N}(4 \mathrm{c})-\mathrm{Pt}(1)$ & $127.2(9)$ & $127.0(8)$ \\
\hline
\end{tabular}


ring forms a dihedral angle averaging to $78.6(2)^{\circ}$. This favours the formation of an intramolecular $\mathrm{H}$ bond between the $\mathrm{N}(3)-\mathrm{H}$ and the thymine oxygen (see Fig. 1, mean values of $\mathrm{N} \cdots \mathrm{O}$ distances and $\mathrm{N}-\mathrm{H} \cdots \mathrm{O}$ angles of $c a .2 .86 \AA$ and $161^{\circ}$, respectively).

The species are stabilized by two intramolecular $\pi-\pi$ interactions given that two phosphine phenyl rings are oriented to stack with the model nucleobases. The centroid-to-centroid distance is shorter for the phenyl-thymine coupling, 3.394(9) $\AA$ with a dihedral angle of $14.9^{\circ}$ (3.413(9) $\AA$ and $14.77^{\circ}$ in complex B), in comparison to the values measured for the phenyl-cytosine pair, of 3.657(10) $\AA$ and $26.46^{\circ}$ (3.887(9) $\AA, 30.39^{\circ}$ in complex B). An additional intramolecular $\pi-\pi$ interaction (not indicated in Fig. 1 and 2) is realized between two, almost parallel, phenyl groups.

The crystal packing evidences both the complexes, located near a center of symmetry, forming pairs of molecules connected by $\mathrm{H}$-bonds occurring between the $\mathrm{N}(4)-\mathrm{H}$ cytosine donor with the thymine oxygen $\mathrm{O}(2)$ of the symmetry related species, the $\mathrm{N} \cdots \mathrm{O}$ distance being $2.992 \AA$ (Fig. 3 and Table 2). A similar arrangement is also detected for the other independent complex B involving $\mathrm{N}(4)-\mathrm{H}$ with $\mathrm{O}(4)$ with a more labile interaction of $3.102 \AA$.

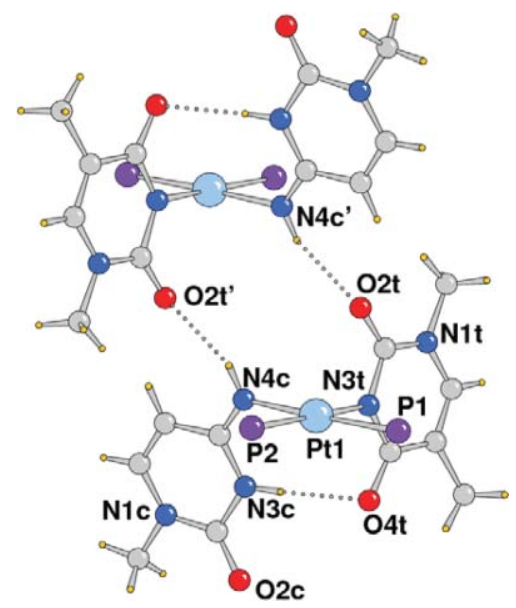

Fig. 3 Crystal packing showing the pairing of complexes about an inversion center with an indication of H-bonds (phosphine phenyl groups not shown for clarity).

Most of the structural features in complexes A and B are similar to those previously described in the complex cis- $\left[\left(\mathrm{PPh}_{3}\right)_{2} \mathrm{Pt}(1-\right.$ $\left.\mathrm{MeCy})\left\{1-\mathrm{MeCy}(-\mathrm{H}), N^{4}\right\}\right]^{+},{ }^{11}$ although in this species the coordination distances showed a reverse trend, being the $\mathrm{Pt}-\mathrm{N}(3)$ bond length is significantly longer $(2.100(3) \AA$ ) than the Pt-N(4a) one (2.061(4) $\AA$ ). Similar to the structure reported here, a N(4)$\mathrm{H} \cdots \mathrm{N}(3)$ hydrogen bond occurs between the bases along with intramolecular $\pi-\pi$ stacking, confirming that the $\mathrm{PPh}_{3}$ derivatives appear stabilized by these interactions.

On the other hand the different crystal packing of cis$\left[\left(\mathrm{PPh}_{3}\right)_{2} \mathrm{Pt}(1-\mathrm{MeCy})\left\{1-\mathrm{MeCy}(-\mathrm{H}), N^{4}\right\}\right]^{+}$(a polymer built by a Hbonding scheme) and of 2a (pair of molecules, see above) could explain the differences observed in the coordination distance values.

\section{Characterisation of cis-[(PMePh $)_{2} \mathbf{P t}\{1-\mathrm{MeTy}(-\mathrm{H})\}-$ $\left(1-\mathrm{MeCy}, N^{3}\right)\left[\mathrm{NO}_{3}(1 \mathrm{~b})\right.$}

With a procedure analogous to that used for the $\mathrm{PPh}_{3}$ derivative, ${ }^{4}$ the thyminate complex cis- $\left(\mathrm{PMePh}_{2}\right)_{2} \mathrm{Pt}\{1-\mathrm{MeTy}(-\mathrm{H})\}\left(\mathrm{ONO}_{2}\right)$ was prepared. The ${ }^{1} \mathrm{H}$ and ${ }^{31} \mathrm{P}$ NMR data of the new compound, in $\mathrm{CDCl}_{3}$ and DMSO, strongly support a structure in which the nitrate group acts as monodentate ligand, as found in the $\mathrm{PPh}_{3}$ analogue. Addition of one equivalent of 1-MeCy affords the mixed complex cis-[(PMePh $\left.)_{2} \mathrm{Pt}\{1-\mathrm{MeTy}(-\mathrm{H})\}\left(1-\mathrm{MeCy}, N^{3}\right)\right] \mathrm{NO}_{3}$ (1) $)$. The spectroscopic analysis of the isolated product is consistent with the presence of the deprotonated 1-MeTy and the neutral $1-\mathrm{MeCy}$, both platinated at the N(3)atom. Due to the different orientations of the nucleobases with respect to the metal coordination plane (Scheme 3), two conformers are expected.

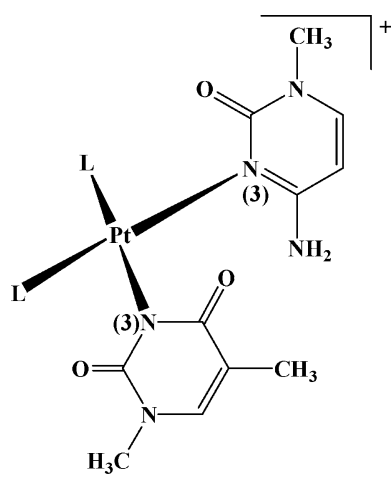

$h t$

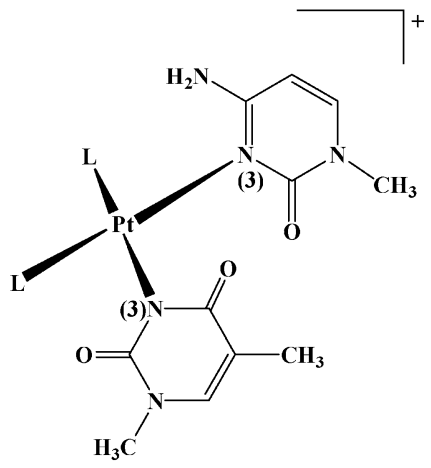

hh
$\mathbf{L}=\mathbf{P M e P h}_{2}$

Scheme 3

Table 2 Intra- and inter-molecular hydrogen bonds

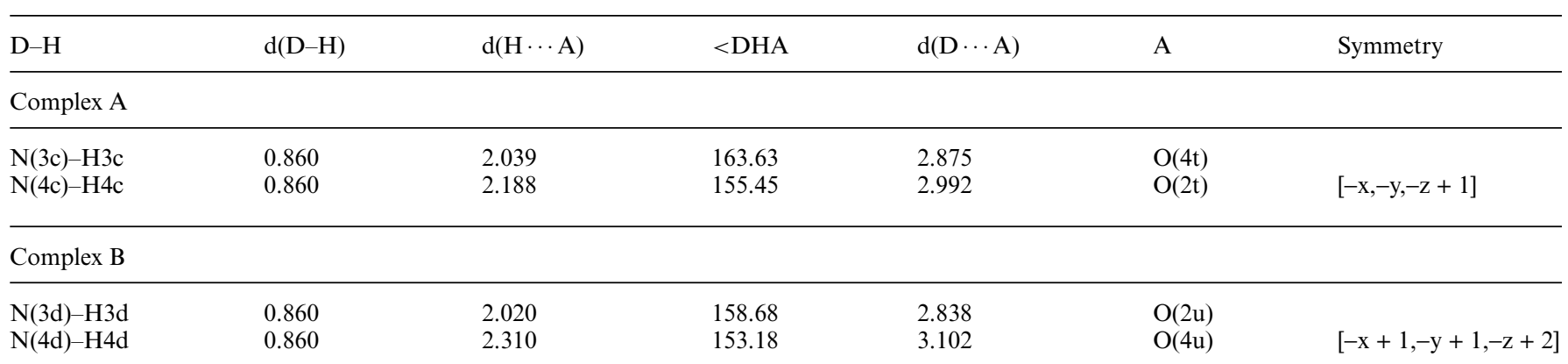

Note: In molecule B the cytosine and thymine bases are labelled as "d" and "u", respectively. 


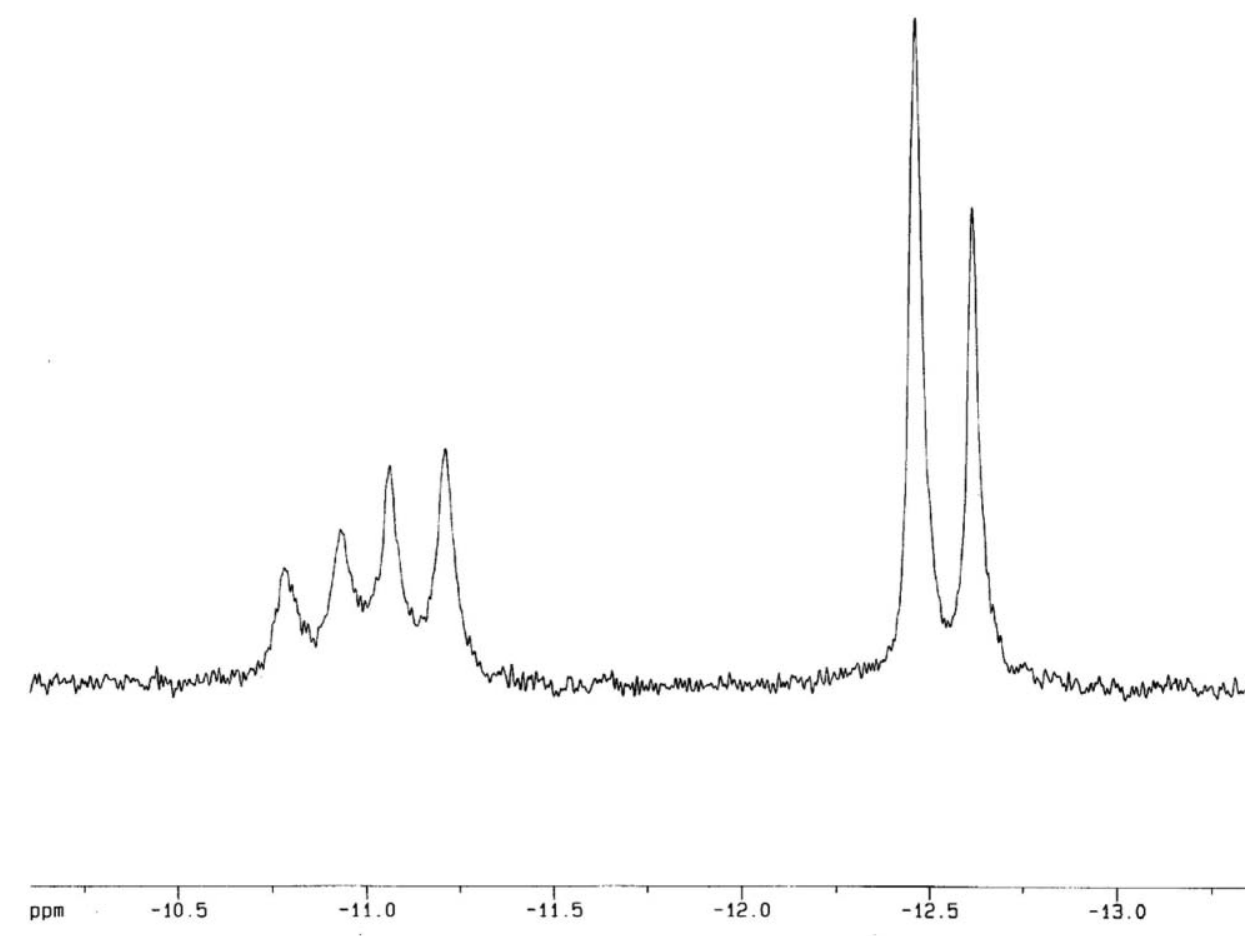

Fig. $4{ }^{31} \mathrm{P}\left\{{ }^{1} \mathrm{H}\right\}$ NMR spectrum of $\mathbf{1 b}$ (central part) in $\mathrm{CDCl}_{3}$ at $25^{\circ} \mathrm{C}$.

In this Scheme, the methyl group, bound to the $\mathrm{N}(1)$ atom in 1-MeCy and 1-MeTy, is oriented in opposite directions in the $h t$ conformer. Accordingly, the ${ }^{31} \mathrm{P}$ NMR spectrum of $\mathbf{1 b}$ in $\mathrm{CDCl}_{3}$ is characterised by two partially overlapped $\mathrm{AB}$ multiplets, of relative intensities 1.5: 1 (Fig. 4). Heterocorrelate ${ }^{31} \mathrm{P}$ and ${ }^{15} \mathrm{~N}$ experiments indicate that the two phosphorous resonances at lower field, having ${ }^{1} \mathrm{~J}_{\mathrm{PPt}}=3249 \mathrm{~Hz}$, are attributable to the phosphine in a trans position to the thyminate ligand.

In the ${ }^{1} \mathrm{H}$ NMR spectrum each nucleobase shows two sets of resonances having relative intensities of $1.5: 1$, whose attribution (see Experimental) was obtained through a COSY experiment. The assignments of the cytosine $\mathrm{NH}_{2}$ protons were obtained through inverse detected ${ }^{1} \mathrm{H},{ }^{15} \mathrm{~N}$ heteronuclear multiple bond coherence experiments (HMBC). In $\mathrm{CDCl}_{3}$, the $\mathrm{NH}_{2}$ resonances are observed at $\delta 8.69$ and $8.60 \mathrm{ppm}$ for the major conformer, and at $\delta 8.75$ and $8.63 \mathrm{ppm}$ for the other. As shown in Figure $A$ in the $\mathrm{ESI}, \uparrow$ the couple of proton signals at lower field correlate with the same $\mathrm{N}(4)$ nucleus $\left({ }^{15} \mathrm{~N}\right.$ at $\left.\delta=-271 \mathrm{ppm}\right)$, whereas the protons at $\delta 8.69$ and $8.60 \mathrm{ppm}$ correlate with the ${ }^{15} \mathrm{~N}$ signal at $\delta=-270 \mathrm{ppm}$ $\left({ }^{1} J_{\mathrm{NH}}\right.$ in the range $\left.80-90 \mathrm{~Hz}\right)$.

The NMR spectra of $\mathbf{1 b}$ in $\mathrm{CDCl}_{3}$, exhibit other very weak resonances, whose attribution remains uncertain. Similar results were obtained in DMSO- $d_{6}$ in which, however, complex $1 \mathbf{b}$ appears in equilibrium with the tautomeric species cis- $\left[\left(\mathrm{PMePh}_{2}\right)_{2} \mathrm{Pt}\{1-\right.$ $\left.\operatorname{MeTy}(-\mathrm{H})\}\left(1-\mathrm{MeCy}, N^{4}\right)\right]^{+}(\mathbf{2 b})$ as clearly indicated by the presence of a weak singlet at $\delta 10.50 \mathrm{ppm}$, attributable to the $\mathrm{N}(3) \mathrm{H}$ proton of the N(4)-coordinated cytosine, and by a weak AX multiplet $\left(\delta_{\mathrm{P}}=-7.05\right.$ and -8.42 with $\left.{ }^{2} \mathrm{~J}_{\mathrm{PP}}=23.4 \mathrm{~Hz}\right)$ in the corresponding ${ }^{31} \mathrm{P}$ NMR spectrum. The relative intensities of the signals indicate that the iminooxo tautomer is $c a$. $7 \%$ of the isomeric mixture and its concentration does not change after several weeks at room temperature.
Since the formal migration of the metal from N(3) to the N(4) site of the cytosine occurs quantitatively in 1a, but only to a minor extent in $\mathbf{1 b}$, the nature of the ancillary ligands plays an important role. The stabilisation of the cytosine ligand in its unusual imooxo tautomeric form is clearly favoured by the bulkier $\mathrm{PPh}_{3}$ molecules, probably for steric reasons. The platination of the cytosine at the $\mathrm{N}(4)$ position, in fact, permits less crowding around the metal being one of the two pyrimidinic rings relatively further away from the coordination center.

In this context, it is interesting to note that the diphosphine analogue, cis-[(dppf)Pt $\left.\{1-\mathrm{MeTy}(-\mathrm{H})\}\left(1-\mathrm{MeCy}, N^{3}\right)\right] \mathrm{BF}_{4}(\mathrm{dppf}=$ 1,1'-bis(diphenylphosphino)ferrocene), ${ }^{12}$ undergoes a similar rearrangement of the cytosine in DMF solution, with a large predominance of the cis-[(dppf)Pt $\left.\{1-\operatorname{MeTy}(-\mathrm{H})\}\left(1-\mathrm{MeCy}, N^{4}\right)\right]^{+}$ species present at the equilibrium. In that case, however, the solid isolated from the mixture turned out to be the starting complex.

\section{Conclusion}

The X-ray structure of the compound cis-[( $\left.\mathrm{PPh}_{3}\right)_{2} \operatorname{Pt}\{1-$ $\left.\operatorname{MeTy}(-\mathrm{H})\}\left(1-\mathrm{MeCy}, N^{4}\right)\right] \mathrm{NO}_{3}$ here reported represents the first example of a phosphino complex in which the neutral 1-MeCy exhibits N(4)-coordination to a metal centre. The two crystallographic independent molecules have been modelled taking into account the conformational isomers previously characterised in solution. ${ }^{4}$ These complexes appear stabilized by strong intramolecular $\pi-\pi$ interactions between the pyrimidinic rings and the phosphine phenyl substituents, allowing the formation of intraand intermolecular hydrogen bonds.

The peculiar properties of the $\mathrm{PPh}_{3}$ ligands in the stabilisation of the cytosine molecule in the iminooxo form stem from the 
following observations: (i) the $\mathrm{PMe}_{3}$ complex, cis-[( $\left.\mathrm{PMe}_{3}\right)_{2} \mathrm{Pt}\{1-$ $\left.\operatorname{MeTy}(-\mathrm{H})\}\left(1-\mathrm{MeCy}, N^{3}\right)\right]^{+}$, in solution slowly rearranges into the polynuclear cytosinate species cis-[( $\left.\left.\mathrm{PMe}_{3}\right)_{2} \mathrm{Pt}\{1-\mathrm{MeCy}(-\mathrm{H})\}\right]_{\mathrm{n}}{ }^{\mathrm{n}+}$ $(\mathrm{n}=2,3)$ and free $1-\mathrm{MeTy}^{4}{ }^{(i i)}$ the tautomeric equilibrium is largely shifted toward the usual $\mathrm{N}(3)$-coordination for $\mathrm{PMePh}_{2}$ derivatives, in particular in chlorinated solvents; (iii) the opposite holds for the dppf analogue of 1a. However, in spite of its thermodynamic stability, we were unable to isolate the iminooxo species, $c i s-\left[(\mathrm{dppf}) \operatorname{Pt}\{1-\mathrm{MeTy}(-\mathrm{H})\}\left(1-\mathrm{MeCy}, N^{4}\right)\right]^{+}{ }^{12}$

\section{References}

1 B. Lippert, Coord. Chem. Rev., 2000, 200-202, 487; B. Lippert, Prog. Inorg. Chem., 2005, 54, 385.

2 B. Lippert, H. Schollhorn and U. Thewald, J. Am. Chem. Soc., 1986, 108, 6616; F. Pichierri, D. Holthenrich, E. Zangrando and L. Randaccio, J. Biol. Inorg. Chem., 1996, 1, 439; J. Müller, E. Zangrando, N. Pahlke, E. Freisinger, L. Randaccio and B. Lippert, Chem. Eur. J.,
1998, 4, 397; P. J. Sanz Miguel, P. Lax, M. Willermann and B. Lippert, Inorg. Chim. Acta, 2004, 357, 4552.

3 B. Lippert, Prog. Inorg. Chem., 1989, 1, 371.

4 D. Montagner, E. Zangrando and B. Longato, Inorg. Chim. Acta, 2009, 362, 725 .

5 B. Longato, G. Bandoli and A. Dolmella, Eur. J. Inorg. Chem., 2004, 1092.

6 T. J. Kistenmacher, M. Rossi, J. P. Caradonna and L. G. Marzilli, $A d v$. Mol. Relax. Interact. Processes, 1979, 15, 119.

7 L. Schenetti, A. Mucci and B. Longato, J. Chem. Soc., Dalton Trans., 1996, 299.

8 Z. Otwinowski, and W. Minor, "Processing of X-ray Diffraction Data Collected in Oscillation Mode". in Methods in Enzymology, ed. C. W. Carter, Jr. and R. M. Sweet, Volume 276, New York, Academic Press, 1997, 307.

9 SHELX97 Programs for Crystal Structure Analysis (Release 97-2), G. M. Sheldrick, University of Göttingen, Germany, 1998.

10 L. J. Farrugia, J. Appl. Crystallogr., 1999, 32, 837.

11 B. Longato, D. Montagner and E. Zangrando, Inorg. Chem., 2006, 45, 8179.

12 G. Bandoli, G. Trovò, A. Dolmella and B. Longato, Inorg. Chem., 1992, 31, 3169. 